\title{
Reference Books of 2016-2017: A Selection
}

\author{
Laurence H. Miller
}

The reference works annotated below are a selection from recent acquisitions in the University of Illinois Library at Urbana-Champaign.

\section{General}

Informationsressourcen für Slawisten. By Katrin Nagovnak. Bibliotheks-und Informationspraxis; vol. 62. Berlin: De Gruyter, 2017. 329 pp.

Purchasers of this excellent guide to online resources for Slavic studies will probably want to download the ebook version because of its convenient links to most of the sources described. The compiler is a librarian in the University of Salzburg Library. The basic European resources are included as well as international and English-language sites, and the book can serve as a textbook on search strategies and techniques. The illustrations are screenshots of basic portals and websites. Descriptions of German and English-language resources for general Slavic studies are in two separate sections. The bulk of the guide includes systematic descriptions of online resources for each of the Slavic nations, and these are easily accessible through the table of contents. Baltic, Central Asian, and other non-Slavic countries are not included, but Slavists in all disciplines will want to consult this and may well discover new approaches and materials for their research.

\section{Belarus}

Udzel'niki paŭstannia 1863-1864 hadoŭ: Biiahrafichny sloŭnik (pavodle matèryialaŭ Natsyianal'naha histarychnaha arkhiva Belarusi). By Dzmitryi Matveichyk. Minsk: Belarus, 2016. 734 pp.

The parallel English title for this work is The Participants of the Rebellion of 18631864: A Biographical Dictionary Based on Materials from the National Historical Archives of Belarus. It includes 7,053 biographical sketches based on 762 archival files. The scholarly introduction has references to the relevant Polish and Russian sources, but there is no reference to non-Belarusian sources in the biographies. All subjects are listed alphabetically by their Belarusian names followed by the Russian form of the name. No Polish, Ukrainian, German, or other form is given. The volume includes indexes of personal names and place names, and a list by fond number of the 762 files consulted. 


\section{Lithuania}

Lietuvos nacionalinis atlasas. Nacionalinė Žemės Tarnyba Prie Žemės Ūkio Ministerijos. Vilnius: Vilniaus Universitetas, 2016. 2 vols.

The English title of Volume 1 of this monumental national atlas of Lithuania is Lithuania in the World and in Europe, Nature and Landscape. Volume 2 is devoted to the history of the country, and English-language descriptions of some 101 outstanding maps are provided.

\section{Poland}

Dzieje więziennictwa polskiego w piśmiennictwie i dokumentach. By Michał Porowski. Warsaw: Wydawnictwa Uniwersytetu Warszawskiego, 2016. 1000 pp.

Eminent Warsaw University penologist Michał Porowski has compiled this annotated bibliography of historical documents and other Polish writing on the legal and political aspects of prisons. The volume includes 2,946 articles arranged alphabetically by author or title and includes bibliographic references. A supplement lists interwar penal institutions along with bibliographic references. Indexes of personal names, geographical terms, and institutional items are included as well as a list of the numerous periodical publications consulted.

Kościót i chrześcijaństwo na ziemiach polskich: Atlas historyczny. By Marek Gędek. Warsaw: Bellona, 2017. 165 pp.

Colorful maps of various sizes fill this useful historical atlas of Polish Christianity and church history from the ninth century to the present, including several maps pertaining to Jewish settlements. The work concludes with a six-page international bibliography of books.

Oficerowie Wojska Polskiego w obozie koncentracyjnym Auschwitz, 1940-1945: Stownik biograficzny. By Jerzy Dębski. Oświęcim: Wydawnictwo Państwowego Muzeum Auschwitz-Birkenau, 2016. 6 vols.

A senior museum historian wrote each article in this biographical dictionary about 1,515 Polish army officers imprisoned at Auschwitz. Each article includes bibliographic references and most are accompanied with prison portraits. The first volume includes an index to the introduction and biographies in that volume, and volume 6 has a personal name index to the complete set.

Polscy adwokaci w obozie koncentracyjnym Auschwitz 1940-1945: Stownik biograficzny (Polish Barristers in the Concentration Camp Auschwitz, 1940-1945). By Jerzy Dębski. Oświęcim: Państwowe Muzeum Auschwitz-Birkenau: Ośrodek Badawczy Adwokatury im. adw. Witolda Bayera przy Naczelnej Radzie Adwokackiej, 2016. 454 pp.

This scholarly work concludes with a thirty-eight page condensed Englishlanguage summary of the 133-page Polish introduction. The introduction includes 
693 footnotes, describes the interwar state of the Polish legal community, and analyzes with a number of statistical tables the status of the imprisoned lawyers. The bulk of the work is a biographical dictionary of members of the legal profession (lawyers, judges, and notaries, 339 in all) in pre-war Poland who were prisoners in the concentration camp in Auschwitz. Biographical articles have a separate bibliography, a source list, and prisoner photographs accompanying many entries. There is a 21-page bibliography and source list. The personal name index mainly refers to the articles, with selective references to the introductory text.

\section{Russia}

Ekaterinburg literaturnyi: Entsiklopedicheskii slovar'. V.A. Blinov and E.K. Sozina, eds. Ekaterinburg: Kabinetnyi uchenyi, 2016. 446 pp.

This regional encyclopedia provides excellent standard coverage of all aspects of literary Ekaterinburg, Sverdlovsk, and environs, and includes black and white portraits, facsimiles, and other photographs. The scholarly signed articles about individual regional authors, literary journals, museums, and circles provide abundant bibliographic notes. There are also smaller articles about famous authors like Evgenii Evtushenko, Aleksandr Solzhenitsyn, and Vladimir Maiakovskii, with incidental connections to Ekaterinburg. The work lacks an index and general bibliography, although there is an article about indexes and literary bibliographies concerning the Ural region.

Iazyk i obshchestvo: Entsiklopediia. V. Iu. Mikhal'chenko, ed. Moscow: Izdatel'skii tsentr “Azbukovnik," 2016. 869 pp.

Sponsored by the Russian Academy of Sciences Linguistics Institute, this authoritative scholarly encyclopedia of the languages used and linguistic circumstances in all areas of the Russian Republic is highly recommended for all Russian reference collections. Included in the introductory matter are a group portrait and brief biobibliographies of Professor Vida Mikhal'chenko and her research team at the Research Center for National Language Relations. Signed scholarly articles with substantial international bibliographies, including dictionaries and language laws, cover virtually every aspect of this subject. Particularly useful are the sociolinguistic analyses of all indigenous languages and numerous articles on the state of sociolinguistics in Russia.

Kto est' kto v russkoi leksikografii. By V.A. Kozyrev and V.D. Cherniak. St. Petersburg: Svoe izdatel'stvo, 2016. $592 \mathrm{pp}$.

Privately printed in 100 copies, this work identifies more than 2,700 lexicographers and more than 3,300 Russian dictionaries from the the end of the seventeenth to the twenty-first century, although primarily from the nineteenth and twentieth centuries. The concluding 188-page bibliography is arranged by author or anonymous title and includes parts of journals and some rarely-held regional works. There are sixty-six titles listed by the great nineteenth century lexicographer Vladimir Dal'. 
Moskovskaia konservatoriia, 1866-2016: Entsiklopediia. M.V. Esipova, ed. Moscow: Progress-Traditsiia, 2016. 2 vols. 670 pp.; 813 pp.

The first volume of this encyclopedia covers the history of the Moscow Conservatory up to the present day and includes many signed articles and a number of black and white and group portraits. The volume has a bibliography and notography arranged chronologically and a list of available recordings (CDs) in both Russian and English. Especially significant for reference purposes is the second volume, a comprehensive scholarly biographical dictionary of Russian and foreign personalities associated with the conservatory. It also includes many signed articles with bibliographic notes.

Narodnichestvo i narodnicheskie partii v istorii Rossii $v$ XX veke: Biobibliograficheskii spravochnik. (Narodnichestvo and Narodnik Parties in XXth century Russian History: Bio-bibliographical Catalog). M.I. Leonov, K.N. Morozov, and A.Iu. Suslov, eds. Moscow: Novyi khronograf, 2016. 543 pp.

This directory and bibliography deals mainly with scholarship on the first quarter of the twentieth century, but scholars of later neopopulist parties are also included. Nine pre-1917 works are listed. Information about foreign historians and publications comes mainly from Internet sources, although information about Russian scholars was obtained through questionnaires and published biobibliographical dictionaries as well. Americans Oliver Radkey and Scott Smith are included. Black and white portraits are included for some of the writers. The bibliography includes 259 document collections and 123 entries for foreign-language works. There is an index of personal names along with a listing of relevant archival fonds. Russian titles $(1,183)$ published after 1991, and presumably uninfluenced by Soviet ideology, occupy a separate section.

Narodnoe sudostroenie v Rossii: Entsiklopedicheskiii slovar' sudov narodnoi postroiki.

By P.A. Filin and S.P. Kurnoskin. St. Petersburg: Gangut, 2016. 395 pp.

Sponsored by the Museum of the World Ocean in Kaliningrad, this scholarly encyclopedia of shipbuilding in Russia includes numerous black and white photographs, line drawings, and plans. The articles include abundant references to archival sources (listed on pages 383-95 and discussed extensively in the introduction). The authors have attempted comprehensive coverage of all types of Russian-built vessels. The geographical scope includes Russian America, Ukraine, Belarus, Moldova, most countries of the Caucasus and Central Asia, but not Poland, Finland, or the Baltic countries.

Rossiia nakanune velikikh potriasenii: Sotsial'no-ekonomicheskii atlas, 1906-1914. V. V. Shelokhaev, ed. Moscow: Kuchkovo Pole, 2017. 668 pp.

This colorful, attractively arranged, and well-documented atlas includes many excellent facsimiles of maps and diagrams from Russian statistical yearbooks, encyclopedias, archival repositories, and other early twentieth-century reference sources. The statistical tables are modernized, include unpublished archival materials, and are accompanied by scholarly footnoted introductions and commentaries. This standard work lacks a general bibliography and index, but it is an outstanding reference source for the social and economic history of Russia during the critical ten years preceding World War I. It should be included in all Russian reference collections. 
Russkaia poeziia XX veka: 1961-1991: Bibliograficheskii spravochnik. By Lev Turchinskii. Moscow: Izdatel'stvo “Truten',” 2016. 627 pp.

Almost 80,000 books of poetry published in Russian during this thirty-year period are included in this comprehensive bibliography arranged alphabetically by author name. Poetry translated into Russian is included.

Russkaia Tserkov' X-XIII vv.: Biograficheskii slovar'. Istoricheskie issledovaniia. By A.Iu. Karpov. Moscow: Kvadriga, 2016. 469 pp.

All known Russian church officials from the second half of the tenth century until 1280 (some 700 names) are included in this scholarly biographical dictionary. A bibliography and list of sources is appended, and additional bibliographic citations accompany the articles.

Russkie fol' kloristy: Biobibliograficheskii slovar': XVIII-XIX vv. Rossiiskaia akademiia nauk. Institut russkoi literatury (Pushkinskii Dom) RAN. T.G. Ivanova, ed. St. Petersburg: Dmitrii Bulanin, 2016. Vol.1. A-G. 957 pp.

This ambitious biobibliography of Russian folklorists grew out of a project initiated in 2008 for an index to Russkii fol' klor. It will be complete in five volumes. Famous and obscure scholars, writers, poets, composers, and musicians in some way associated with folklore are included, and exhaustive bibliographic and archival research was undertaken to achieve the goal of comprehensive coverage. The major German, English, and French sources are cited.

Severnyi ledovityi okean: Entsiklopediia. By I.S. Zonn, A.G. Kostianoi, and A.V. Semenov. 2d. ed. rev. and enl. Moscow: CHOUVO "Moskovskii universitet im. S.Iu. Vitte,” 2016. 2 vols. 502 pp.; 452 pp.

About 1500 articles are included in these volumes with some color portraits and illustrations. Volume 2 has a chronology of major historical events from 870-2016 (118 pp.), a brief bibliography, and a list of Internet addresses-sources.

Spravochno-bibliograficheskaia literatura po russkomu fol' kloru. By T. G. Ivanova. St. Petersburg: Dmitrii Bulanin, 2017. 142 pp.

Leading folklore scholar-bibliographer Tatiana Grigorievna Ivanova of Pushkinskii Dom has provided this sorely needed guide to research in Russian folklore. Sponsored by her institution and the Saint Petersburg Conservatory, this invaluable resource describes the basic bibliographic and archival sources in the field, as well as motif and tale-type indices, encyclopedias and biographical dictionaries, and folkloric data in historical and subject dictionaries. Aimed at advanced students in ethnomusicology and philology, this work is an outstanding reference tool for Russian specialist librarians and bibliographers.

Staropechatnaia kirillicheskaia kniga XVI-XVII vekov; Katalog kollektsii. By E.V. Platonov, O.N. Mal'tseva, and S.A. Kudriavtsev. St. Petersburg: Izdatel'stvo Gosudarstvennogo Ermitazha, 2016. 342 pp.

The relatively small collection of 125 titles (179 copies) of early printed Cyrillic books (mainly from the Moscow Printing House) in the Hermitage is painstakingly 
described with excellent facsimile reproductions of text pages and bindings. The introductory essays by Evgeny Platonov and Olga Maltseva are in both Russian and English, whereas the supplementary essay by Sergei Kudriavtsev accompanying the facsimiles of stamping instruments and blocks is only in Russian. A bibliography and several indexes enhance the book's reference value. EBS Editoriale Bortolazzi-Stei printed the edition in Verona.

Vysshee chinovnichestvo Rossiiskoi imperii: Kratkii slovar'. By S.V. Volkov. Moscow: Universitet Dmitriia Pozharskogo, 2016. 798 pp.

This useful biographical reference work is arranged alphabetically and lists more than 22,000 individuals who attained one of the top four civil ranks in the Russian beauracracy from the beginning of the eighteenth through the beginning of the twentieth centuries. Persons in the fifth class in the eighteenth century are also included. The entries are typically one or two lines including birth and death dates and brief biographical data from the official service lists.

\section{Serbia}

Pregled jevrejske periodike u Srbiji (od 1888. do 2015. godine). By Biljana Albahari. Belgrade: Savez jevrejskih opština Srbije, 2016. 124 pp.

Facsimiles of covers and front pages accompany the annotations for the seventy-three Jewish periodicals in this bibliography. Languages of publication include Serbo-Croatian, Serbian, Hungarian, German, Ladino, and Yiddish. The author states that most of the titles are available in the Jewish Historical Museum and National Library of Serbia in Belgrade and the library of Matica Srpska in Novi Sad. Some of the entries also refer to unique holdings in the National and University Library in Zagreb, and some periodicals have not survived. The work concludes with a two-page summary in English, a bibliography, and several useful indexes.

\section{Ukraine}

Malorossiiskie dela: Opisi fonda no. 124 Rossiiskogo gosudarstvennogo arkhiva drevnikh aktov. T.G. Tairova-Iakovleva, V.V. Mushchinskaia, and A.V. Bagro, eds. Moscow: Drevlekhranilishche, 2016.649 pp.

This RGADA archival inventory is a companion volume to Malorossiiskii prikaz: Opisi fonda no. 229 Rossiiskogo gosudarstvennogo arkhiva drevnikh aktov (St. Petersburg, 2012), both works issued by the Center for the Study of the History of Ukraine at St. Petersburg University. It includes commentary and indexes of personal and geographic names. Both works are basic reference aids for libraries serving early Slavic historians. 